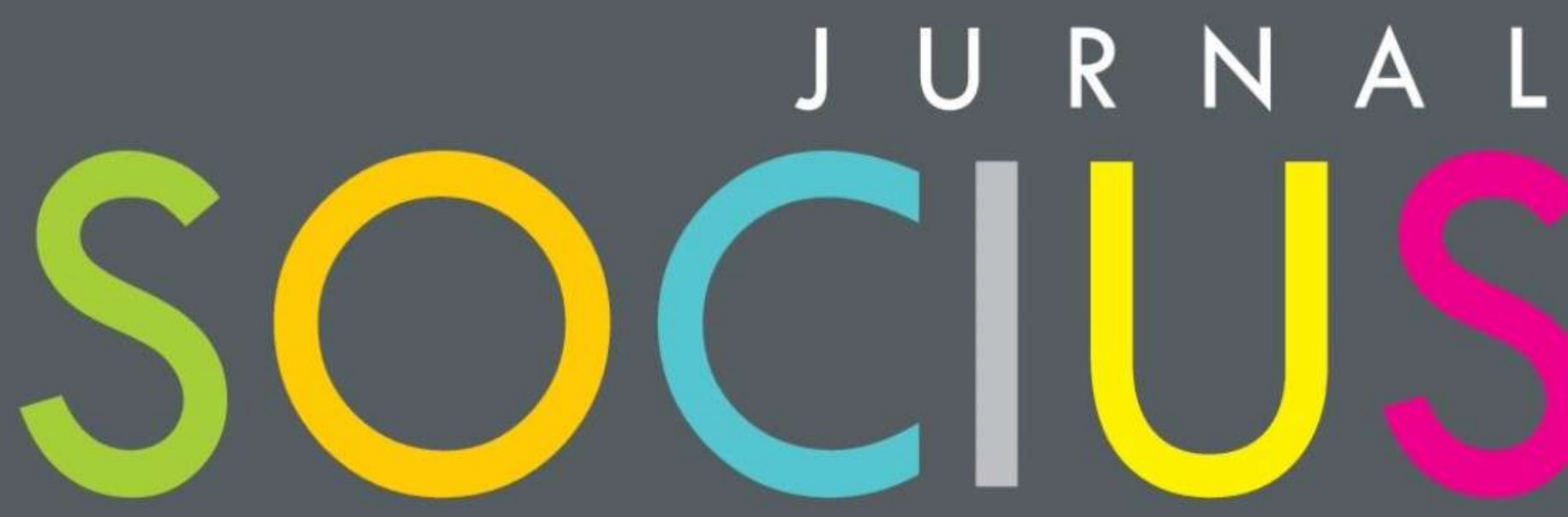

Journal of Sociology Research and Education

DITERBITKAN OLEH :

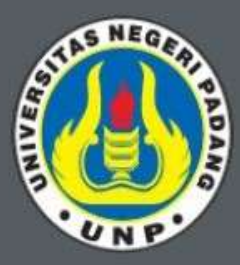

LABOR JURUSAN SOSIOLOGI FAKULTAS ILMU SOSIAL UNIVERSITAS NEGERI PADANG

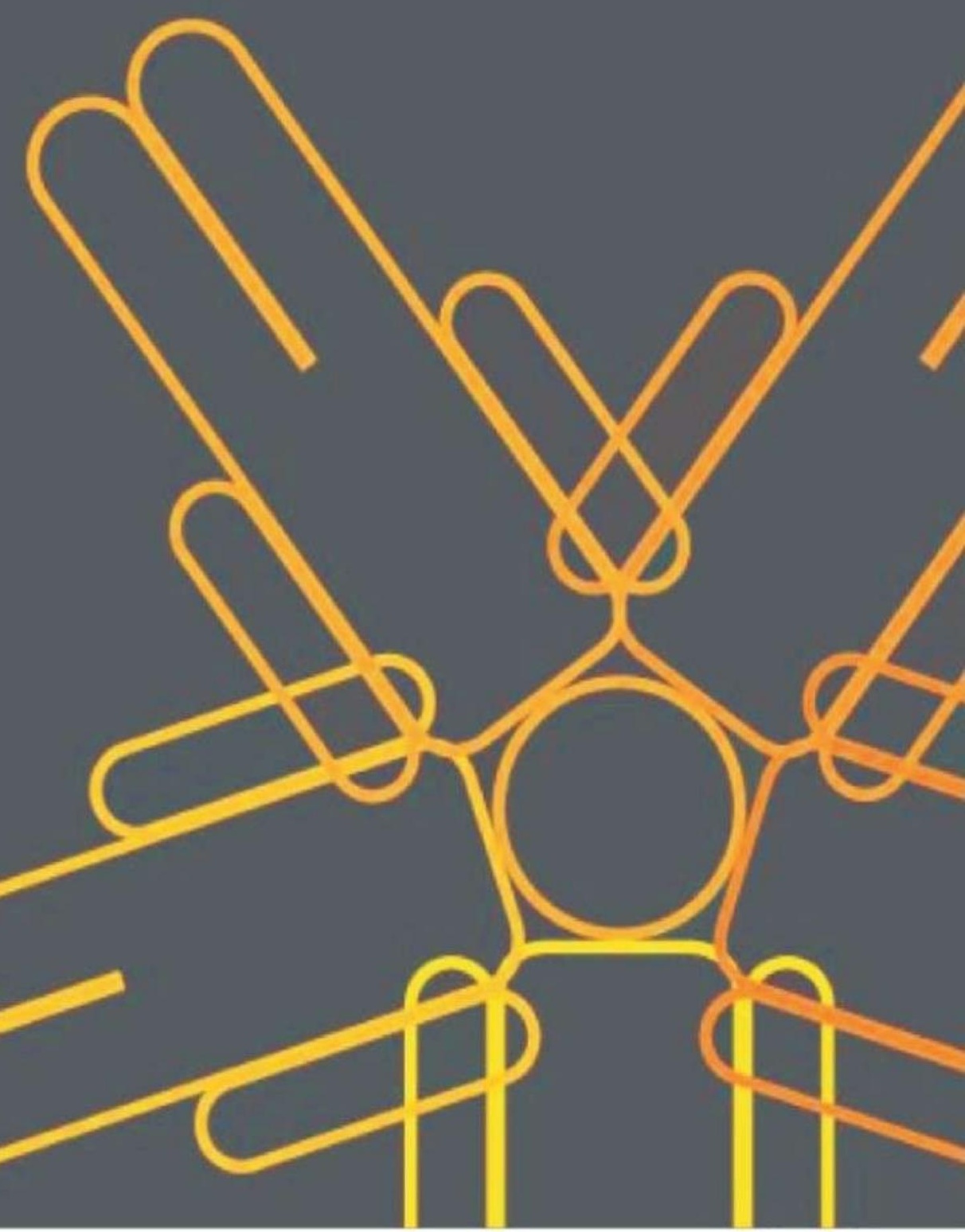




\section{SOCIUS}

Vol. 6, No.1, Th. 2019

ISSN : 2356-4180 (cetak)

2442-8663 (online)

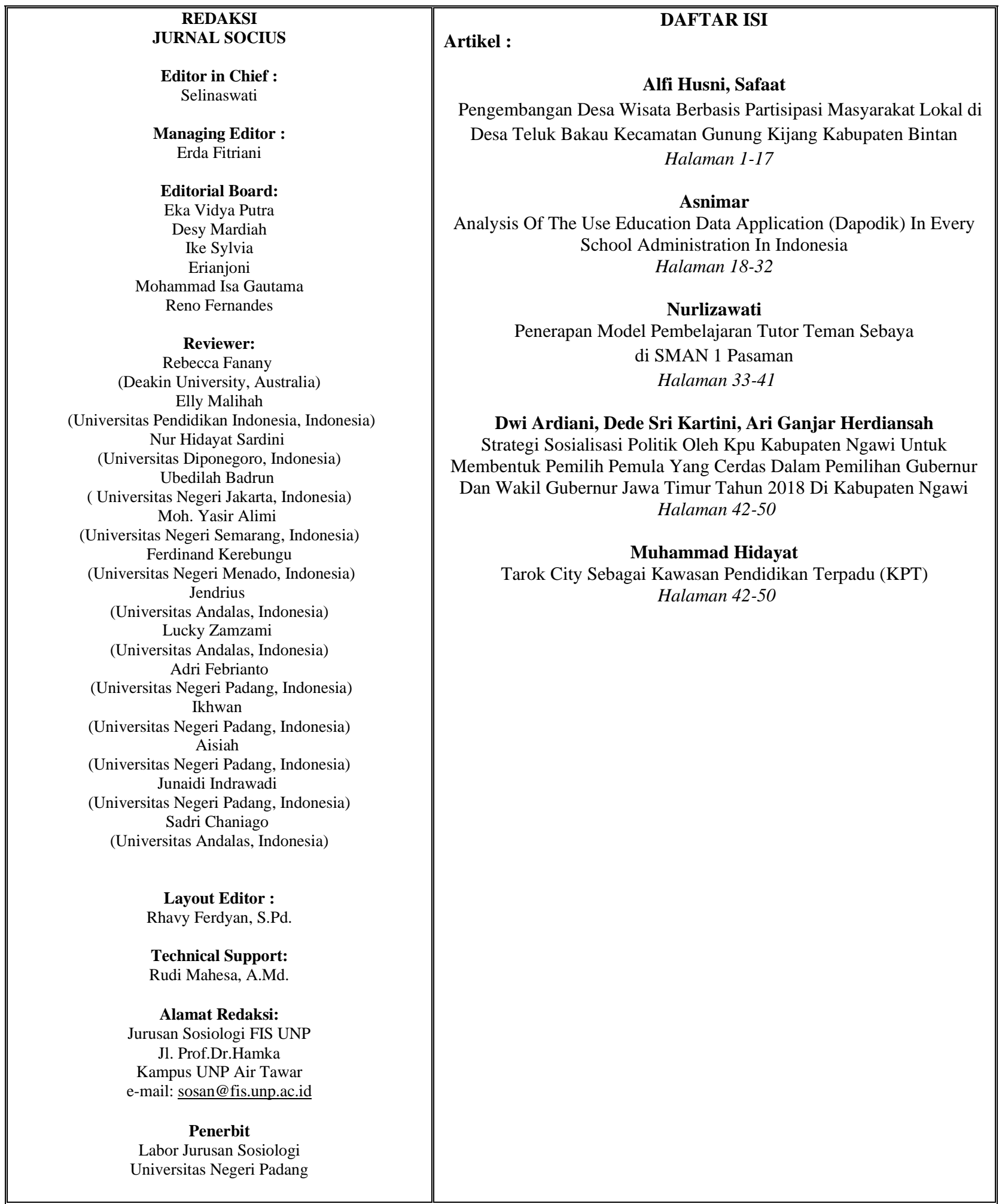




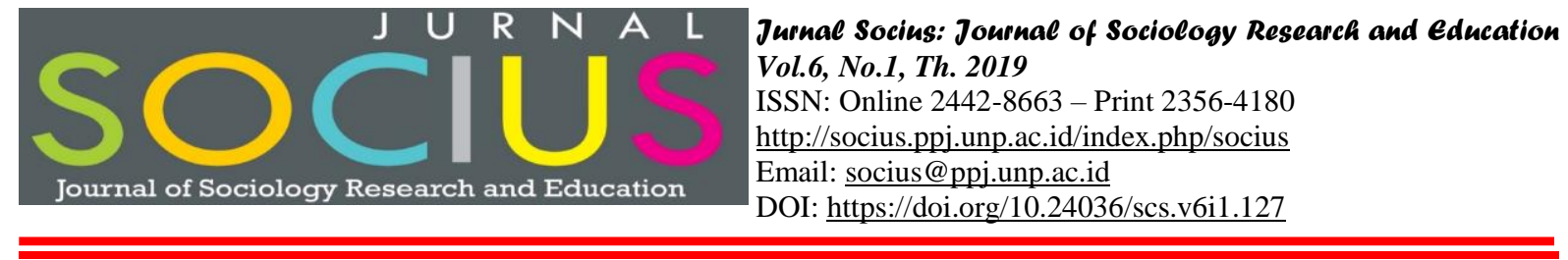

\title{
PENERAPAN MODEL PEMBELAJARAN TUTOR TEMAN SEBAYA DI SMAN 1 PASAMAN
}

\author{
Nurlizawati \\ Universitas Negeri Padang \\ Email: $\underline{\text { lizaqyuter@gmail.com }}$
}

\begin{abstract}
Abstrak
Penelitian ini bertujuan untuk mengimplementasikan pembelajaran lesson study dengan memfasilitasi tumbuhnya komunitas belajar melalui tutor teman sebaya pada mata pelajaran sosiologi di SMA Negeri 1 Pasaman Barat. Penelitian ini merupakan penelitian tindakan kelas (PTK), yang bertujuan untuk meningkatkan kemampuan kolaboratif (colaboration) dan komunikatif (communication) siswa sebagai aspek 4C yang harus dikembangkan pada peserta didik di abad 21. Penelitian ini dilaksanakan di kelas XI IPS SMA Negeri 1 Pasaman Barat. Hasil penelitian yang diperoleh adalah pertama pada aspek kognitif siswa dapat lebih mudah memahami materi karena melalui tutor teman sebaya terbangun perilaku potensial melalui pengorganisasian materi pembelajaran secara mandiri dalam bentuk bantuan belajar selama proses belajar secara lebih intensif karena jarak psikologis yang minimal antara tutor dan tutee. Kedua, pada aspek afektif akan terjadi hubungan interaksi yang lebih erat antara peserta didik dan guru. Ketiga, Pada aspek keterampilan diharapkan akan terjadi peningkatan kemampuan kolaboratif dan komunikatif peserta didik. Pada akhirnya diharapkan pelaksanaan lesson study selama penelitian, juga telah mempererat kolegalitas antara tim peneliti dan guru mitra, membentuk mutual learning (saling belajar), terbentuknya komunitas belajar dan meningkatkan profesional guru sebagai pendidik dan pengajar
\end{abstract}

Kata kunci: Metode Tutor Teman Sebaya, Lesson Study, Communication, Collaborative, Pembelajaran Sosiologi

\section{Abstract}

This study aims to implement lesson study learning by facilitating the growth of the learning community through peer tutoring on sociology subjects in SMA Negeri 1 Pasaman. This research is classroom action research (PTK), which aims to improve students' collaborative (communicative) and communicative (communication) abilities as a $4 \mathrm{C}$ aspect that must be developed in students in the 21st century. This research will be conducted in class XI IPS in SMA 1 Pasaman. The expected research results are first on the cognitive aspects of students can more easily understand the material because through peer tutoring potential behavior will be built through organizing independent learning material in the form of seeking help and giving help during the learning process more intensively due to minimal psychological distance between tutors and tutee. Second, in the affective aspect there will be a closer interaction between students and teachers. Third, in the aspect of skills, it is expected that there will be an increase in the collaborative and communicative abilities of students. In the end, it was expected that the implementation of Lesson Study during the study had also strengthened the collegiality between the research team and the partner teachers, formed mutual learning (formation of mutual learning), the formation of learning communities and improved professional teachers as educators and instructors.

Key Word: Peer tutoring method, Lesson Study, Communication, Collaborative, Sociology studies

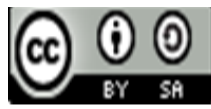




\section{Pendahuluan}

Di abad ke 21 ini, pendidikan menjadi semakin penting untuk menjamin peserta didik memiliki keterampilan belajar dan berinovasi, keterampilan menggunakan teknologi dan media informasi, serta dapat bekerja, dan bertahan dengan menggunakan keterampilan untuk hidup (life skills). Kurikulum 2013 merupakan kurikulum yang menekankan adanya keterampilan abad 21. Salah satu aspek penting dalam perubahan kurikulum 2013 adanya keterampilan yang harus dimiliki oleh peserta didik yaitu ketrampilan 4C (Critical thinking, Communication, Collaborative dan Creative). Kurang terasahnya kemampuan siswa dalam komunikasi dan bekerja sama merupakan sebuah permasalahan penting yang menggangu proses pembelajaran. Pembelajaran sosiologi merupakan pembelajaran yang menuntut aspek kognitif, dalam hal ini sangat memerlukan ketrampilan komunikasi (communication) dan kerja sama (collaborative).

Penggunaan proses Lesson Study dengan program-program pengembangan yang profesional tersebut merupakan wahana untuk mengembalikan guru kepada budaya mengajar yang proporsional. Pembelajaran dengan menggunakan kegiatan Lesson Study tentunya dapat membantu guru dalam dalam memperbaiki proses pembelajaran, agar siswa dapat menguasai ketrampilan communication dan collaborative salah satunya dapat difasilitasi melalui tutor teman sebaya. Pembelajaran dengan memanfaatkan teman sebaya yang lebih paham terhadap materi merupakan cara yang efektif dalam memudahkan komunikasi antar siswa. Menurut Zuraidah (2003) pembelajaran dengan memanfaatkan tutor sebaya dapat membantu rekan sebaya dalam aspek akademis, emosi disiplin. Dengan bantuan tutor sebaya pembelajaran akan lebih efektif, komunikatif dan efisien karena bahasa tutor lebih mudah dipahami. Dengan bantuan tutor sebaya ini peserta didik dijadikan sebagai subjek pembelajaran yaitu peserta didik yang diajak untuk dijadikan tutor atau sumber belajar dan tempat bertanya bagi teman sejawatnya. Bahasa yang digunakan mudah dipahami dan hubungan interpersonal antara teman sejawat terjalin dengan baik, sehingga terjadi transaksi pembelajaran yang efektif, aktif, inovatif dan komunikatif. Tulisan ini memaparkan hasil penelitian penerapan metode tutor teman sebaya dalam meningkatkan kemampuan collaborative dan communication dalam pembelajaran sosiologi di SMAN 1 Pasaman.

\section{Kajian Pustaka}

Metode tutor sebaya adalah suatu metode pembelajaran yang dilakukan dengan cara memberdayakan siswa yang memiliki daya serap yang tinggi dari kelompok siswa itu sendiri untuk menjadi tutor bagi teman-temannya, dimana siswa yang menjadi tutor bertugas untuk memberikan materi belajar dan latihan kepada teman-temannya (tutee) yang belum faham terhadap materi/ latihan yang diberikan guru dengan dilandasi aturan yang telah disepakati bersama dalam kelompok tersebut, sehingga akan terbangun suasana belajar kelompok yang bersifat kooperatif bukan kompetitif. Lesson study merupakan suatu pendekatan peningkatan kualitas pembelajaran yang awal mulanya berasal dari Jepang. Di Negara tersebut, kata atau istilah itu lebih popular dengan sebutan Jugyokenkyu. Lesson study dikembangkan oleh Makoto Yoshida". Lesson study adalah model pembinaan (pelatihan) profesi pendidik melalui pengkajian pembelajaran secara kolaboratif dan berkelanjutan berlandaskan prinsip-prinsip kolegialitas dan mutual learning untuk membangun komunitas belajar (Sumar Hendayana, dkk, 2009: 5). Selain itu Styler dan Hiebert (Susilo, 2009: 3) mengatakan bahwa: Lesson study adalah suatu proses kolaboratif pada sekelompok guru ketika mengidentifikasikan masalah pembelajaran, merancang suatu skenario pembelajaran (yang meliputi kegiatan mencari buku dan artikel mengenai topik yang akan diajarkan); membelajarkan peserta didik sesuai dengan skenario (salah seorang guru melaksanakan pembelajaran sedangkan yang lain mengamati), mengevaluasi dan merevisi skenario pembelajaran, membelajarkan lagi skenario pembelajaran

Jurnal Socins: Journal of Sociology Research and Education Vol. 6, No.1, Th. 2019 
yang telah direvisi, mengevaluasi lagi pembelajaran dan membagikan hasilnya dengan guruguru lain (mendiseminasikannya). Berdasarkan pernyataan di atas lesson study merupakan sebuah kegiataan pembelajaran yang digunakan untuk memperbaiki proses pembelajaran yang dapat digabungkan dengan metode lainnya. Dalam penelitian ini lesson study akan dipadukan dengan metode tutor teman sebaya dalam meningkatakan ketrampilan communication dan collaboration dalam pembelajaran sosiologi. Menurut Alwi (2009) ada pengaruh yang signifikan dari metode tutor teman sebaya terhadap motivasi belajar matematika siswa SMA. Hal ini berarti bahwa penerapan metode pembelajaran tutor sebaya akan meningkatkan motivasi belajar matematika siswa SMA. Tutor teman sebaya adalah perekrutan salah satu mahasiswa guna memberikan satu per satu pengajaran kepada mahasiswa lain, dalam menyelesaikan tugas yang diberikan melalui partisipasi peran tutor dan tutee. Tutor memiliki kemampuan lebih dibandingkan tutee, tapi pada beberapa variasi tutorial jarak pengetahuan yang dimiliki antara tutor dan tutee minimal (Roscoe \& Chi, 2007).

Pembelajaran dengan memanfaatankan teman sebaya yang lebih paham terhadap materi merupakan cara yang efektif dalam memudahkan komunikasi antar siswa. Menurut Zuraidah (2003) pembelajaran dengan tutor sebaya dapat membantu rekan sebaya dalam aspek akademis, emosi disiplin. Dengan bantuan tutor sebaya pembelajaran akan lebih efektif, komunikatif dan efisien karena bahasa tutor lebih mudah dipahami. Dengan bantuan tutor sebaya ini peserta didik dijadikan sebagai subjek pembelajaran yaitu peserta didik yang diajak untuk dijadikan tutor atau sumber belajar dan tempat bertanya bagi teman sejawatnya. Bahasa yang digunakan mudah dipahami dan hubungan interpersonal antara teman sejawat terjalin dengan baik, sehingga terjadi transakasi pembelajaran yang efektif, aktif, inovatif dan komunikatif. Berdasarkan pendapat di atas maka dapat dikatakan bahwa dengan menggunakan pembelajaran tutor teman sebaya akan lebih memudahkan komunikasi antar siswa dan memberikan keleluasaan pada siswa dalam berkomunikasi tentang materi yang tidak dapat dipahaminya.

Ilmu sosiologi merupakan ilmu yang berkembang pertama kali di Eropa. Roucek dan Warren mengemukakan bahwa Sosiologi adalah ilmu yang mempelajari hubungan antara manusia dalam kelompok-kelompok. Selo Soemardjan dan Soelaeman Soemardi menyatakan bahwa Sosiologi atau ilmu masyarakat adalah ilmu yang mempelajari struktur sosial dan proses-proses sosial, termasuk perubahan-perubahan sosial. William F. Ogburn dan Meyer F. Nimkoff berpendapat bahwa Sosiologi adalah penelitian secara ilmiah terhadap interaksi sosial dan hasilnya yaitu organisasi sosial (Soerjono Soekanto, 2007: 18).

Mata pelajaran Sosiologi diajarkan secara khusus untuk mencapai tujuan-tujuan khusus sebagai berikut;

1. Meningkatkan penguasaan pengetahuan Sosiologi di kalangan peserta didik yang berorientasi pada pemecahan masalah dan pemberdayaan sosial;

2. Mengembangkan pengetahuan Sosiologi dalam praktek atau praktek pengetahuan Sosiologi untuk meningkatkan keterampilan sosial peserta didik dalam memecahkan masalah-masalah sosial;

3. Menumbuhkan sikap religius dan etika sosial yang tinggi di kalangan peserta didik sehingga memiliki kepekaaan, kepedulian dan tanggungjawab memecahkan masalahmasalah sosial;

Untuk mencapai tujuan pembelajaran sosiologi yang tertuang dalam kurikulum 2013 ini dibutuhkan pembentukan ketrampilan communicaton dan collaboration. Maka dari itu ketrampilan 4C khususnya communication dan collaboration harus dikuasai olah siswa dan dibantu oleh guru melalui penerepan metode tutor teman sebaya dalam kegiatan lesson study. Kecakapan komunikasi dalam proses pembelajaran antara lain sebagai berikut. 
a) Memahami, mengelola, dan menciptakan komunikasi yang efektif dalam berbagai bentuk dan isi secara lisan, tulisan, dan multimedia (ICT Literacy).

b) Menggunakan kemampuan untuk mengutarakan ide-idenya, baik itu pada saat berdiskusi, di dalam dan di luar kelas, maupun tertuang pada tulisan.

c) Menggunakan bahasa lisan yang sesuai konten dan konteks pembicaraan dengan lawan bicara atau yang diajak berkomunikasi.

d) Selain itu dalam komunikasi lisan diperlukan juga sikap untuk dapat mendengarkan, dan menghargai pendapat orang lain, selain pengetahuan terkait konten dan konteks pembicaraan.

e) Menggunakan alur pikir yang logis, terstruktur sesuai dengan kaidah yang berlaku.

f) Dalam Abad 21 komunikasi tidak terbatas hanya pada satu bahasa, tetapi kemungkinan multi-bahasa.

Kolaborasi dalam proses pembelajaran merupakan suatu bentuk kerjasama dengan satu sama lain saling membantu dan melengkapi untuk melakukan tugas-tugas tertentu agar diperoleh suatu tujuan yang telah ditentukan.

Kecakapan terkait dengan kolaborasi dalam pembelajaran antara lain sebagai berikut.

a) Memiliki kemampuan dalam kerjasama berkelompok

b) beradaptasi dalam berbagai peran dan tanggungjawab, bekerja secara produktif dengan yang lain.

c) Memiliki empati dan menghormati perspektif berbeda.

d) Mampu berkompromi dengan anggota yang lain dalam kelompok demi tercapainya tujuan yang telah ditetapkan.

\section{Metodologi Penelitian}

Jenis penelitian yang digunakan dalam penelitian ini adalah Penelitian Tindakan Kelas (PTK) dengan pendekatan deskriptif kualitatif. Menurut Luthfian Almash dkk (1998:12) Penelitian tindakan kelas adalah suatu bentuk penelitian yang bersifat reflektif dengan melakukan tindakan-tindakan tertentu agar dapat memperbaiki dan atau meningkatkan praktek-praktek pembelajaran di kelas secara lebih profesional. Menurut Anas Yasin (2011: 6) penelitian tindakan kelas memberikan ketrampilan kepada guru dalam memecahkan masalah khusus yang berkenaan dengan kelasnya. Dengan menggunakan prosedur penelitian, guru yang meneliti dapat menghadapi tantangan di dalam pembelajaran mereka sendiri.

PTK selain bertujuan untuk meningkatkan hasil belajar, juga untuk meningkatkan kinerja guru dan dosen dalam proses pembelajaran. Dengan kata lain, PTK bukan hanya bertujuan untuk mengungkapkan penyebab dari berbagai permasalahan yang dihadapi, tetapi yang lebih penting adalah memberikan pemecahan berupa tindakan untuk mengatasi masalah. Dengan demikian dapat disimpulkan bahwa PTK adalah suatu penelitian yang dilakukan untuk mengatasi masalah-masalah yang ada dalam proses pembelajaran dan upaya meningkatkan proses serta hasil belajar.

Penelitian Tindakan Kelas ini dilakukan dengan mengintegrasikan Lesson Study. Penelitian dilakukan dalam 2 siklus, di mana dalam setiap siklus terdapat empat tahap, yaitu perencanaan, pelaksanaan, observasi, dan refleksi. Pada setiap open class dilakukan Lesson Study yang meliputi tahapan plan, do, dan see. Kehadiran peneliti dalam penelitian ini adalah sebagai observer yang merancang kegiatan pembelajaran atau tindakan yang dilakukan bersama-sama dengan tim lesson study dan guru model diperankan oleh guru sosiologi di SMA 1 Pasaman. Penelitian ini dilakukan di SMA Negeri 1 Pasaman kelas XI. Penelitian ini dilakukan pada bulan Oktober (semester I tahun pelajaran 2018/2019). Untuk mendapatkan data disetiap pertemuannya peneliti menggunakan lembar observasi dimana variabel yang diteliti ialah: Kerjasama, Komunikasi, bertanya, menjawab, dan menaggapi. 
Subjek penelitian ini adalah semua siswa kelas XII IPS5 SMAN 1 Pasaman. Jumlah seluruh siswa kelas XII IPS 5 yang terdaftar pada tahun 2017-2018 sebanyak 27 siswa. Teknik penelitian yang digunakan adalah teknik total sampling, artinya semua populasi dijadikan sampel sebagai subjek penelitian. Pengambilan sampel bisa dilihat pada tabel berikut:

Tabel 1. Populasi dan subjek penelitian

\begin{tabular}{lllc}
\hline No & Siswa & Populasi & Sampel \\
\hline 1 & Perempuan & 19 & 19 \\
\hline 2 & Laki-laki & 8 & 8 \\
\hline & Jumlah & 27 & 27 \\
\hline
\end{tabular}

Rencana tindakan yaitu gambaran tentang langkah-langkah ril yang akan dalam penelitian. Menurut Lewin (1946) ada 4 tahap yang dilalui dalam penelitian tindakan kelas ini, yaitu: (1) Perencanaa, (2) Pelaksanaan,(3) Pengamatan, (4) Refleksi. Adapun model penelitian tindakan kelas untuk masing-masing tahap adalah sebagai berikut ;

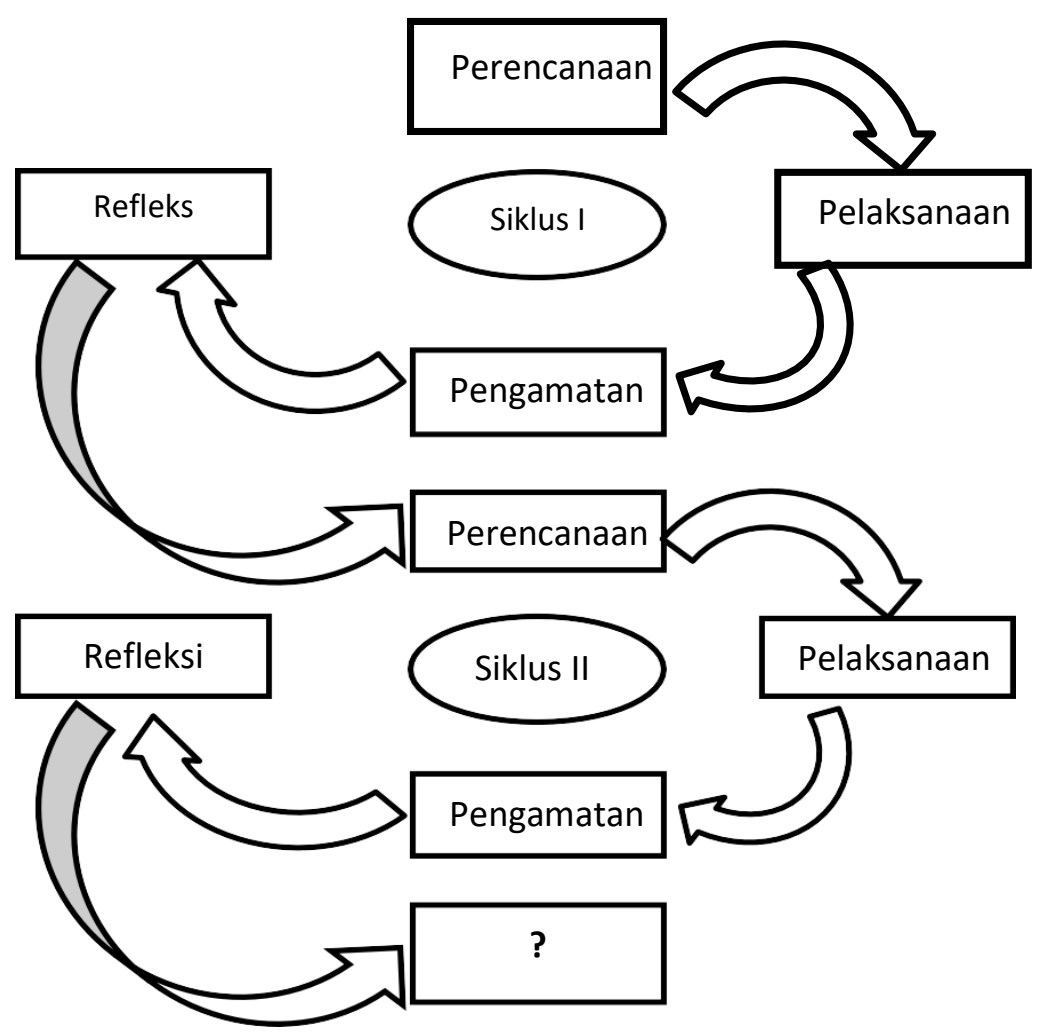

Gambar 1. Penelitian Tindakan Kelas Kurn Lewin

Instrumen yang digunakan dalam penelitian ini terdiri dari lembar observasi dan catatan lapangan. Data pengisian lembar observasi aktivitas belajar siswa dianalisis dalam bentuk persentase. Data jumlah siswa yang terlibat masing-masing aktivitas dipersentasekan dengan rumus: $P=\frac{F}{N} X 100 \%$ 


\section{Hasil dan Pembahasan}

Berdasarkan penelitian yang dilakukan di SMA Negeri 1 Pasaman yang mana penelitian ini terdiri dari dua siklus dengan mengkolaborasikan kegiatan lesson study dalam pembelajaran sosiologi, yang masing-masing siklus terdiri dari tahapan persiapan dan pelaksanaan. Data yang diperoleh dari kegiatan siswa dalam lembaran observasi setiap pertemuan 1 dan 2 siklus I dan II setelah dilakukan tindakan adalah sebagai berikut.

\section{Tabel 2. Rekapitulasi data ketrampilan communcation Siklus I dan Siklus II}

\begin{tabular}{|c|c|c|c|}
\hline \multirow{3}{*}{ No } & \multirow{3}{*}{ Aspek Kegiatan Siswa yang Diamati } & \multicolumn{2}{|c|}{ Jumlah Siswa Tiap Pertemuan } \\
\hline & & Siklus I (\%) & Siklus II (\%) \\
\hline & & 1 & 2 \\
\hline $\mathbf{A}$ & Ketrampilan communication & & \\
\hline $\mathbf{1}$ & Mengajukan pertanyaan & 48 & 66,67 \\
\hline 2 & Menjawab pertanyaan & 51,8 & 62,96 \\
\hline 3 & Mengemukakan Pendapat & 37 & 62,96 \\
\hline 4 & Membuat Kesimpulan & 44 & 62,96 \\
\hline 5 & Mengerjakan Latihan & 92,5 & 100 \\
\hline 6 & Membuat laporan hasil diskusi & 55,5 & 55,5 \\
\hline 7 & Mendengarkan pendapat lawan bicara & 74,1 & 74,1 \\
\hline 8 & $\begin{array}{l}\text { Menggunakan media untuk menunjang } \\
\text { informasi dalam diskusi }\end{array}$ & 44,4 & 51,85 \\
\hline 9 & $\begin{array}{l}\text { Menggunakan bahasa lisan yang sesuai konten } \\
\text { dan konteks pembicaraan dengan lawan bicara } \\
\text { atau yang diajak berkomunikasi. }\end{array}$ & 33,3 & 66,67 \\
\hline 10 & $\begin{array}{l}\text { Sikap menghargai pendapat orang lain, selain } \\
\text { pengetahuan terkait konten dan konteks } \\
\text { pembicaraan. }\end{array}$ & 85,18 & 88,89 \\
\hline 11 & $\begin{array}{l}\text { Menggunakan alur pikir yang logis, terstruktur } \\
\text { sesuai dengan kaidah yang berlaku. }\end{array}$ & 70,4 & 70,4 \\
\hline 12 & $\begin{array}{l}\text { Mampu menggunakan multi bahasa salah } \\
\text { satunya seperti bahasa inggris }\end{array}$ & 26 & 48,14 \\
\hline & Jumlah rata-rata & 55,18 & 67,59 \\
\hline
\end{tabular}

Berdasarkan data yang diperoleh peneliti dari pelaksanaan observasi terhadap aktivitas keterampilan berkomunikasi yang dilakukan oleh siswa dengan metode tutor teman sebaya dalam kegiatan lesson study dapat diketahui tingkat aktivitas siswa. Apakah aktivitas siswa rendah, cukup, tinggi atau sangat tinggi, sehingga dapat diketahui peningkatan aktivitas yang diharapkan. Aktivitas siswa pada tabel dapat diukur secara kualitatif dan kuantitatif. Untuk menentukan kriteria tersebut dipakai kriteria yang dikemukakan oleh Arikunto (1991: 71), yaitu:

a. $80-100$ : sangat tinggi

b. $60-80$ : tinggi

c. $40-60$ : cukup

Jurnal Socius: Journal of Sociology Research and Education Vol. 6, No.1, Th. 2019 
d. $20-40$ : rendah

e. $0-20 \quad$ : rendah

Kriteria siswa yang aktif pada siklus I masih rendah, sudah mulai menampakkan keaktifan dalam belajar, namun peneliti belum merasa pada batas yang diharapkan, karena pada siklus I masih ada siswa yang belum aktif berkomunikasi dalam proses pembelajaran. Maka penulis merasa perlu melanjutkan ke siklus II. Pada siklus pertama ketrampilan komunikasi siswa kelas XII IPS 5 masih sekitar 55, 18\% yang dapat kita kategorikan bahwa dikelas ini siswa cukup memilki ketrampilan berkomunikasi. Metode tutor teman sebaya ini mampu meningkatkan keterlibatan siswa dalam bekomunikasi. Karena tutor teman sebaya ini memotivasi siswa-siswa dengan bantuan temannya yang memiliki pengetahuan yang lebih. Kelebihan dari menggunakan tutor teman sebaya ini secara psikologis siswa menjadi lebih senang belajar, karena tidak begitu berjarak dengan tutornya. Karena tutornya adalah temannya sendiri, hal ini memudahkan siswa kelas XII IPS 5 untuk berkomunikasi dalam proses pembelajaran. Secara keseluruhan pada siklus I dan siklus II terjadi peningkatan ketrampilan berkomunikasi pada siklus II. Rata-rata kenaikan persentase rata-rata siklus I dengan siklus II dengan rata-rata naik dari 55,18\% menjadi $67.59 \%$.

Menurut Zuraidah (2003) pembelajaran dengan memanfaatkan tutor sebaya dapat membantu rekan sebaya dalam aspek akademis, emosi disiplin. Dengan bantuan tutor sebaya pembelajaran akan lebih efektif, komunikatif dan efisien karena bahasa tutor lebih mudah dipahami. Penggunaan model pembelajaran tutor sebaya dapat membantu siswa dalam penerimaan materi pelajaran. Model pembelajaran ini dapat juga membantu guru untuk meningkatkan keaktifan siswa di dalam kegiatan pembelajaran karena dengan model ini siswa dituntut untuk lebih aktif dalam kegiatan pembelajaran, dan dapat memotivasi siswa terutama dalam kegiatan pembelajaran sosiologi. Metode tutor teman sebaya ini dapat membentuk komunitas belajar antar siswa, karena siswa tidak merasa berjarak dengan siswa lain. Manfaat lain dari tutor teman sebaya dengan kegiatan lesson study dapat menumbuhkan ketrampilan untuk collaborative. Berikut data collaborative siswa kelas XII IPS 5

\section{Tabel 3. Rekapitulasi Data Ketrampilan Collaborative Kegiatan Siswa Kelas XII IPS 5 Siklus I dan Siklus II}

\begin{tabular}{clcc}
\hline \multirow{2}{*}{ No } & Aspek Kegiatan Siswa yang Diamati & \multicolumn{2}{c}{ Jumlah Siswa Tiap Pertemuan } \\
\cline { 3 - 4 } $\mathbf{B}$ & Keterampilan collaborative & Siklus I (\%) & Siklus II (\%) \\
\hline $\mathbf{1}$ & $\begin{array}{l}\text { Memiliki kemampuan dalam kerjasama } \\
\text { berkelompok }\end{array}$ & 33,33 & 48,15 \\
\hline $\mathbf{2}$ & Beradaptasi dalam berbagai peran & 55,55 & 74,1 \\
\hline $\mathbf{3}$ & $\begin{array}{l}\text { Tanggungjawab terhadap tugas yang } \\
\text { diberikan, }\end{array}$ & 33,33 & 70,37 \\
\hline $\mathbf{4}$ & $\begin{array}{l}\text { Bekerja secara produktif dengan yang } \\
\text { lain. }\end{array}$ & 25,9 & 89,7 \\
\hline $\mathbf{5}$ & $\begin{array}{l}\text { Memiliki empati dan menghormati } \\
\text { perspektif berbeda. }\end{array}$ & 88,89 & 81,5 \\
\hline $\mathbf{6}$ & $\begin{array}{l}\text { Mampu berkompromi dengan anggota } \\
\text { yang lain dalam kelompok demi } \\
\text { tercapainya tujuan yang telah } \\
\text { ditetapkan }\end{array}$ & 59,2 & 70,51 \\
\hline \multicolumn{1}{c}{ Jumlah rata-rata } \\
\hline
\end{tabular}


Berdasarkan data yang diperoleh peneliti dari pelaksanaan observasi terhadap aktivitas ketrampilan berkomunikasi yang dilakukan oleh siswa dengan metode tutor teman sebaya dalam kegiatan lesson study dapat diketahui tingkat aktivitas siswa. Kemampuan bekerjasama/collaborative siswa dengan menggunakan metode tutor teman sebaya melalui kegiatan lesson study lebih terlihat, karena siswa akan bekerja sama dengan siswa yang lain dalam menyelesaikan tugas kelompok yang diberikan oleh guru model. Peningkatan kemampuan bekerja sama siswa kelas XII IPS 5 pada siklus 1 49,37\% tergolong cukup, pada siklus ke 2 siswa lebih mampu bekerja sama dengan baik, hal ini dapat dilihat dari persentase collaborative yang sebesar 70,51 \% (baik). Keterampilan collaborative merupakan ketarampilan yang diharapkan ada pada siswa saat ini, karena dunia kerja mengharapkan adanya kemampuan untuk bisa bekerjasama dengan orang lain. Kolaborasi dalam proses pembelajaran merupakan suatu bentuk kerjasama dengan satu sama lain saling membantu dan melengkapi untuk melakukan tugas-tugas tertentu agar diperoleh suatu tujuan yang telah ditentukan. Dalam mengembangkan keterampilan collaborative di kelas XII IPS 5 SMAN 1 Pasaman, tidak terlepas dari kerjasama guru dalam membuat plan pembelajaran yang mengutamakan adanya kerjasama kelompok dengan menggunakan metode tutor teman sebaya.

\section{Penutup}

Kegiatan lesson study dengan menggunakan metode tutor teman sebaya dapat meningkatkan ketrampilan communication dan collaborative yang pada akhirnya akan membentuk komunitas belajar antar siswa. Bagi guru kegiatan lesson study merupakan kegiatan yang mampu membetuk komunitas belajar antar guru dalam mempersiapakan pembelajaran yang efektif. Metode tutor teman sebaya mampu meningkatkan keterlibatan siswa dalam berkomunikasi. Karena tutor teman sebaya ini memotivasi siswa-siswa dengan bantuan temannya yeng memiliki pengetahuan yang lebih. Kelebihan dari menggunakan tutor teman sebaya ini secara psikologis siswa menjadi lebih senang belajar, karena tidak begitu berjarak dengan tutornya

Secara keseluruhan pada siklus I dan siklus II terjadi peningkatan keterampilan berkomunikasi pada siklus II. Rata-rata kenaikan persentase rata-rata siklus I dengan siklus II dengan rata-rata naik dari 55,18\% menjadi $67.59 \%$. Peningkatan kemampuan bekerja sama (collaborative) siswa kelas XII IPS 5 pada siklus 1 49,37\% tergolong cukup, pada siklus ke 2 siswa lebih mampu bekerja sama dengan baik, hal ini dapat dilihat dari persentase collaborative yang sebesar 70,51\% (baik).

\section{Daftar Pustaka}

Arikunto, S. (2009). Prosedur Penelitian Suatu Pendekatan Praktik Edisi Revisi 6. Jakarta: Rineka Cipta

Almash, Luthfiah, dkk. (1998). Penelitian Tindakan Kelas. Padang: IKIP Padang

Anas Yasin. (2011). Penelitian Tindakan Kelas: Tuntunan Praktis. Padang: Bung Hatta University Press.

Alwi, M. (2009). Pengaruh metode tutor sebayaterhadap motivasi dan prestasi belajar matematika siswa SMA. Tesis Fakultas Psikologi UGM, Yogyakarta.

Kurt, Lewin. (1946). Action Research and Minority Problems. Journal of Social, 1(2).

Podhorsky, C. \& Moore, V. (2006). Issues in Curriculum: Improving Instructional PracticeThrough Lesson Study.http://www.lessonstudy.net. 
Roscoe, R.D., \& Chi, M.T.H. (2007). Understanding tutor learning: Knowledge building and knowledgetelling in peer tutors' explaination and questions. Review of Education Research, 77 (4): 534-574.

Soekanto, Soerjono. (2007). Sosiologi Suatu Pengantar. Jakarta: PT. Rajagrafindo Persada

Sumar, Hendayana. (2006). Lesson Study Suatu Strategi Untuk Meningkatkan Keprofesionalan Pendidikan. Bandung: UPI Press.

Susilo, H. (2006). Apa dan Mengapa Lesson Study Perlu Dilakukan untuk Meningkatkan Profesionalisme Guru dan Dosen MIPA. Makalah. Disajikan dalam Seminar Peningkatan Profesionalisme Guru dan Dosen MIPA melalui Lesson Study, di Singaraja, 25 November 2006.

Susilo, Herawati, et. al., (2009). Lesson Study Berbasis Sekolah. Malang: Bayu Media.

Zuraidah, A. R. (2003). Pembimbing rekan sebaya satu pendekatan logikal. Tersedia pada: http//www.geocities.com/prshm/stu-pendekatanlogic.html. Di akses pada tanggal 18 desember 2017. 